\title{
International Economic Law and Policy: A Comprehensive and Critical Analysis of the Historical Development
}

\author{
Mohammad Belayet Hossain, Saida Talukder Rahi \\ School of Law, Chittagong Independent University of Bangladesh (CIUB), Chittagong, Bangladesh \\ Email: hasan1215@yahoo.com, galib@ciu.edu.bd
}

How to cite this paper: Hossain, M. B., \& Rahi, S. T. (2018). International Economic Law and Policy: A Comprehensive and Critical Analysis of the Historical Development. Beijing Law Review, 9, 524-546. https://doi.org/10.4236/blr.2018.94031

Received: April 24, 2018

Accepted: September 22, 2018

Published: September 25, 2018

Copyright $\odot 2018$ by authors and Scientific Research Publishing Inc. This work is licensed under the Creative Commons Attribution International License (CC BY 4.0).

http://creativecommons.org/licenses/by/4.0/

\section{(c) (i) Open Access}

\begin{abstract}
The aim of this article is to analyse the evolution of international economic law and its fundamental principles. It will examine the current framework of international economic law and the efforts made to regulate international economic relations between states as part of an attempt to establish a global order. It will begin by surveying efforts made prior to the establishment of the $\mathrm{UN}$, and will then focus on developments that have taken place since the establishment of the UN. The objective of the article is to provide a comprehensive and critical appraisal of the law developed to govern economic relations between different states, and between states and private economic actors such as multinational enterprises.
\end{abstract}

\section{Keywords}

International Economic Law, Bretton Woods Institutions, The World Bank, The International Monetary Fund (IMF), General Agreement on Tariffs and Trade (GATT)

\section{Introduction}

International economic law is a massive body of law, which is growing rapidly and changing fast. It seeks to regulate more or less all aspects of international economic relations between states. International economic law developed as a separate and identifiable body of law in the post-Second World War era. Prior to this, the law relating to international economic activities (e.g. the protection of foreign investment) was at a rudimentary stage and was regarded as part of public international law. The Bretton Woods Institutions were set up in 1944, which are the World Bank, and the International Monetary Fund (IMF). The aim of 
creating these institutions was based on notions of consensual decision-making and cooperation in the realm of trade and economic relations. A multilateral framework was necessary to overcome the destabilising effects of the previous global economic depression and trade battles and to help rebuild the shattered post-war economy and to promote international economic cooperation between states. After creations of Bretton Woods institutions, the General Agreement on Tariffs and Trade was established in 1948 with a view to eliminate harmful trade protectionism, removing tariffs, boosting international trade and restoring economic health to the world after the devastation of World War II. However, GATT was replaced by the more robust World Trade Organization (WTO) in 1995.

This article will discuss how economic relations between peoples and countries have developed over time, giving rise to new challenges for the law. Much of international economic law has developed relatively recently in response to the growth in international economic activity. As the expansion of international economic activity increased contacts among people of different nations, this interaction had to be regulated by international law. In the early years of the development of international economic law, the law dealt mainly with the nature of the legal relationship between a state and a foreign company engaged in the exploitation of its natural resources. It is in this context that this article will examine the evolution of select key principles of international economic law. This article will also examine the definition of international economic law, the fundamental principles of this body of law and developments in other areas of international law that have influenced the development of international economic law.

\section{Sources of International Economic Law}

Sources of international economic law are also sources of general international law, as codified in Article 38 of the Statute of the International Court of Justice (ICJ). This article is generally regarded as providing the most authoritative listing of international law sources. They are:

1) Treaties;

2) International customs;

3) General principles of law;

4) Judicial decisions of international courts and tribunals and the teachings of the most highly qualified international lawyers as subsidiary means for determining the rules of law.

Treaties have the pre-eminent role in developing international economic law, but the practice of states is also important. The practice of states acquires the character of customary law when a particular practice meets the test of generality, uniformity and consistency and is coupled with a legal conviction on the part of states that they are obliged to follow it by law. This psychological element is called opiniojuris (Cassese, 2005). 


\section{From Antiquity to Empires}

The word "antiquity" means "ancient past", which especially refers to the period of classical and other human civilizations before the Middle Ages. The "empire" generally refers to "an extensive group of states or countries under a single supreme authority or a large commercial organization owned or controlled by one person or group".

Since time immemorial the first and foremost objective of the law has been to maintain law and order in society. When people in antiquity began to organise themselves as societies on the basis of some rules to govern the activities of the members of their society, the primary occupation of the law was to maintain law and order in society. From its outset, the legal system of society advanced civilisation by maintaining law and order and creating a mechanism for settlement of disputes through third-party involvement. This prevented members of society from taking the law into their own hands and retaliating individually for any alleged injustices meted out to them by other members of the society.

Those not content with this basic objective of the law began to expand its role by using it for social engineering with a view to advancing civilisation, promoting justice (both social and economic) and achieving greater prosperity and happiness for members of society. Since time immemorial, people have endeavoured to create wealth and to surpass the older generation in attaining higher standards of living, prosperity and happiness. This led some to venture out of their local communities and interact with people from other communities for trade and commerce (WTO Secretariat, 1999).

The level of interaction grew as science and technology advanced. New modes of travel made it easy for explorers and adventurers to travel out in their missions to faraway countries. Traders then followed them. Thanks to these traders, people living in remote areas and in the harsh weather conditions of northern Europe began to taste the richness of life enjoyed by the people of southern Europe, the Mediterranean and Arabia. Consequently, the volume of trade and the level of interaction between the people of these faraway countries grew. With this growth, people belonging to different national communities began to learn more about the lives and cultures of the people of foreign nations. This was the beginning of the first phase of globalisation, and the challenge for law (which would later be termed international law) was to regulate the relations of people living under different sovereign entities scattered all over the world.

When societies began to organise themselves as political entities, those with common aspirations began to form alliances, giving rise to the formation of states. The most powerful and ambitious rulers strove to bring as many states as possible under their sway to create vast empires. Such empires needed massive amounts of wealth to sustain them. On the basis of the wealth that they amassed, imperial rulers embarked upon breathtaking projects in different spheres of human activity, ranging from building physical infrastructure such as palaces, castles, monuments, roads and bridges to promoting arts and culture. 
However, in time these empires began to crumble under their own weight as they were, by and large, artificial entities held together on the basis of force and oppression. The nations and peoples living under the empires began to assert their freedom. This process ultimately gave rise to the birth of modern nation states in Europe. The Peace of Westphalia of 1648 was a major landmark in the history of both international law and international relations. It was this treaty, which acted as a catalyst for the downfall of the Holy Roman Empire and the birth of the modern nation state in Europe (Lowenfeld, 2003).

\section{From Empires to Modern Nation States}

When these nation states became organised, they too began to see whether the world outside their boundaries offered any opportunities for wealth creation and the betterment of their peoples' lives. Various missions were commissioned by these nation states to explore what lay beyond the vast waters of the oceans to the east, west and south. The explorers and adventurers who set off from their European homelands in their journeys to unknown territories were to return with exciting tales to tell about faraway lands together with samples of exotic items collected during their missions overseas, enticing the rulers and the populace of the country to embark on ever bigger overseas missions. This was the beginning of the second phase of globalisation and empire creation by nation states (Qureshi, 2002). These explorers and adventurers became the catalyst for a profound change in international relations in the centuries to come. People living in Western Europe were now in active and direct contact with the people of Asia, Africa and the Americas. The Europeans grew to like the richness of life enjoyed by the people of Arabia, South and South-east Asia and the Far East and the volume of trade between these faraway territories began to grow.

With trade came missionaries to spread their religion, and with the help of traders, missionaries, adventurers and explorers the nation states of Western Europe began to create their own empires by colonising the newly discovered lands. This global interaction between the native peoples of Asia, Africa and Latin America on the one hand and the Europeans on the other was the beginning of a new phase of globalisation.

\section{The Colonial Era and Effect of Decolonisation}

It was during the period of colonisation that international law began to evolve as a body of law governing relations between states. The first phase of international law-making was Eurocentric and was designed to regulate affairs among the European powers themselves. The colonial powers were often at war with each other but their relations had to be regulated to ensure some degree of peace at home. Their relations vis-à-vis their colonial territories overseas also had to be regulated so that there was a smooth colonial rule (Qureshi, 1999). The Congress of Vienna of 1815 and the Treaty of Versailles of 1919 were designed primarily to settle disputes between the warring states of Europe. The establishment of the 
League of Nations together with the creation of a Permanent Court of International Justice and the International Labour Organization marked the beginning of a new phase of globalisation. ${ }^{1}$

These institutions sought to identify and advance the common values of the international community based on the desire to institutionalise peace. Bound by the rules of the Covenant of the League of Nations and the provisions of the General Agreement of Peace of 1928, a spirit of international community of nations emerged. The objectives of this community were to act for the betterment of humanity. However, the colonial powers were in fierce competition with each other for dwindling world resources in order to meet the economic aspirations of their rulers and populations. Competition for wealth among the European powers and the desire to bring as many colonial territories as possible within their control led to many wars among them, including the First and Second World Wars.

When the First World War weakened the capitalist countries of Europe, they resorted to protectionist measures to defend their economic interests, rather than promoting the ideals of free trade. Therefore the inter-war period was a time of economic disorder among the different capitalist countries on the one hand and between capitalist countries and newly independent states on the other. The spirit of the community of nations suffered a huge setback when the Second World War broke out in Europe. Moreover, during and prior to the outbreak of hostilities in Europe, nations under colonial rule elsewhere were struggling for independence. Just as nations within the old European empires had sought freedom from their imperial rulers, so nations under colonial rule began to assert their freedom from that rule (Seidl-Hohenveldern, 1992).

Consequently, various waves of independence gave freedom to nations under colonial rule. The independence of the Latin American states was followed by the independence of many Asian and African countries, which started gaining their independence in the aftermath of the Second World War. The independence of these countries posed new challenges to international economic relations, as they sought to attain their own aspirations and ambitions. As these newly independent states started to assert their sovereign rights, they came into conflict with the interests of those foreign powers who had an economic interest in their territory. For instance, when the newly independent states of Latin America asserted their economic sovereignty by claiming that their national laws would apply to foreign investors, the investor countries challenged this assertion.

The argument advanced by the investor countries was that international law (or more precisely, international minimum standards) rather than national law applied to foreign investors. It was against this backdrop that the norms of modern international economic law began to evolve and the Eurocentric nature of international law began to acquire a global character. It was also during this phase of international law-making that international law sought to regulate not

${ }^{1}$ http://www.icj-cij.org 
only economic relations, but also matters relating to:

1) disarmament;

2) the use of force;

3) the conduct of states during time of war;

4) the peaceful settlement of disputes (Muchlinski, 1999).

The Latin American countries gradually came to accept international minimum standards in their treatment of foreign investors through various human rights instruments relating to the Americas. By contrast, the newly independent states of Asia and Africa were more assertive of their economic sovereignty and attempted to rewrite the existing international law concerning economic relations through the platform provided by the UN. ${ }^{2}$ However, the capitalist countries resisted this tendency and sought to defend the existing rules of international economic law, which mostly served the interests of capitalism. Soon after the establishment of the UN, two camps of states, one led by the US and the other by the former USSR, became locked in a "Cold War" that lasted for nearly 40 years. During this time a polarised form of globalisation was in existence. In 1989-90 the "free world" of capitalism, democracy and individual freedom triumphed over communism. A new phase of globalisation now began. This current phase has been the most comprehensive and all-encompassing so far, bringing about far-reaching changes in almost all spheres of human activity (Fox, 1992).

\section{The Aspirations of Newly Independent States}

The number of independent developing states grew dramatically in the 1950s and 1960s, thanks to the success of independence movements in Asia, Africa, the Pacific and the Caribbean. The economic order created in the aftermath of the Second World War with the establishment of the Bretton Woods institutions-the World Bank, the International Monetary Fund (IMF) and the General Agreement on Tariffs and Trade (GATT) - was no longer capable of fully addressing the world's economic problems in this changed context. ${ }^{3}$

GATT 1947 was premised on the idea of creating a "level playing field" in the conduct of the international trade. This was not acceptable to the newly independent developing countries, which sought help from the international community to be able to compete on an equal footing and also benefit from the GATT regime. What is more, the developing countries did not confine their aims to changes to the GATT system, but had much more ambitious dreams for themselves. They sought to restructure the whole international economic order in order to bring about international justice-a cherished goal of the international community outlined in the Preamble to the Charter of the UN.

Consequently, the decolonisation period of the 1950s and 1960s was characterised by conflict on both the economic and political fronts between developed and developing countries. When the newly independent states of Asia and Africa 
started acting jointly with the Latin American states, they embarked on a policy designed to achieve economic equality between states by proposing a restructuring of international economic relations.

\section{The Idea of Sustainable Economic Development}

The attempts made in the 1960s and 1970s within the UN to define the nature of the legal relationship between a host state and a foreign company sought to define the competence of a sovereign state to expropriate and regulate foreign companies operating within it. They did not seek to regulate the unhindered exploitation of natural resources by states themselves. With the exception of a UN resolution of 1962 designed to endorse a call by UNESCO to enact effective domestic legislation to preserve natural resources (including flora and fauna ${ }^{4}$ ), the emphasis was very much on establishing the right of states in international law to exploit their natural resources in accordance with their own development policies. As well as various international economic law instruments, various human rights instruments adopted in the period from the 1960s to the 1980s sought to establish and strengthen the right of states and peoples to freely dispose of their wealth and natural resources (Schrijver, 1997). Examples include:

1) the 1966 International Covenant on Civil and Political Rights (ICCPR); ${ }^{5}$

2) the 1966 International Covenant on Economic, Social and Cultural Rights (ICESCR); ${ }^{6}$

3) the 1981 African Charter on Human and Peoples' Rights. ${ }^{7}$

Even the resolutions of the UN concerning the new international economic order $(\mathrm{NIEO})^{8}$ and the Charter of Economic Rights and Duties of States ${ }^{9}$ adopted in the mid-1970s (i.e. during the heyday of the triumph of the Third World countries within the UN) did not introduce the element of sustainability or any need for countries to consider the environment while engaging in the exploitation of their natural resources.

Thus, traditionally speaking, the idea of sustainable development or the need to conserve natural resources was missing in the main corpus of international economic law. It was only through developments taking place elsewhere (mainly in the area of international environmental law) that the idea of sustainable economic development and the need to conserve natural resources was introduced onto the agenda of international economic law.

The Charter of the UN (the "world constitution") entrusted the UN with an

${ }^{4}$ The UN General Assembly adopted a resolution in 1962 on economic development and the conservation of nature (Resolution 1831 (XVII)) in which it expressed its consciousness of the extent to which economic development of developing countries might jeopardise their natural wealth and resources, including flora and fauna. As Schrijver notes, through this resolution the Assembly was endorsing "a call by UNESCO to enact effective domestic legislation covering, inter alia, the preservation and rational use of natural resources."

${ }^{5}$ Article 47 of the ICCPR.

${ }^{6}$ Article 25 of the ICESCR.

${ }^{7}$ Article 21 of the African Charter.

${ }^{8}$ G.A.Res. 3201 (S-VI) and 3202 (S-VI) of 1 May 1974.

${ }^{9}$ G.A.Res. 3281 (XXIX) of 12 December 1974. 
overall responsibility for formulating policies designed to:

1) achieve higher standards of living for the people of the world;

2) address problems of an economic character.

Consequently, the UN began to work from quite early on for the economic development of developing countries. It did not simply react to economic events, but was also proactive in formulating policies designed to address the problem of the underdevelopment. The activities of the UN and its specialised agencies in this regard have evolved in phases, as follows:

\subsection{Technical Assistance}

During the first phase of UN activities (i.e. between its establishment and the late 1950s), its activities focused mainly on developing the human resources of developing countries and providing technical assistance to them. The number of developing countries was small and their ambition limited. Providing technical assistance was seen by both the UN and developed countries as the starting point for furthering their development. The absorbing capacity of the developing countries was limited. What they needed at an early stage of their economic development was technical assistance in the form of expert manpower and related assistance.

\subsection{Economic Sovereignty}

As the number of developing countries grew within the UN, thanks to accelerating decolonisation, they started to assert their economic independence and champion a more just and fair world economic system. Between the late 1950s and the late 1960s, the international development agenda moved on from providing technical assistance to creating institutions such as the UN Conference on Trade and Development (UNCTAD) to ensure that the international institutions took the needs and aspirations of developing countries more seriously. Developing countries began to challenge some of the existing principles of international economic law in favour of a system, which met their aspirations. In doing so, they wished to introduce some reform of the Bretton Woods institutions, especially within the GATT system. They also wished to introduce the development agenda into GATT.

\section{Restructuring of the World Economy}

The 1960s was an exciting decade, raising human expectations and ambitions. People saw that it was possible to go to outer space and reach the moon, and towards the end of the decade the world came to know that there was a huge reserve of mineral resources in the deep seabed. It was during this decade that a large number of states gained independence-many of them with little or no bloodshed. It was a positive and progressive time in many respects, but it was also tumultuous. The Cold War reached new heights, the two superpowers of the day came close to all-out nuclear war during the Cuban missile crisis and developing countries sought to restructure the world economy through the UN. 


\subsection{Third World Countries Assert Themselves}

During this decade the gap between rich and the poor widened dramatically. The nations that had gained independence realised that the existing world economic order was not conducive to their economic development. Encouraged by the numerical majority that they had now acquired within the UN and the solidarity that they enjoyed, the developing countries decided to pursue a proactive policy aimed at the redistribution of wealth through the UN.

The idea was first to halt the unilateral expansion and exploitation of the world's resources by a few technologically advanced and economically powerful countries and then to introduce rules designed to achieve equality of opportunity and justice for all. Consequently, while the 1967 Treaty on Outer Space sought to prevent unilateral claims over outer space and other celestial bodies by those with the technological ability to travel in space, the 1970 Declaration of the Common Heritage of Mankind sought to halt unilateral claims over areas of the deep seabed and unilateral exploitation of the resources therein.

When the developing countries gained a numerical majority in the UN, they sought to use the UN system to introduce much more fundamental reform of the international economic system. In a sense, the 1970s was the "heyday" for developing countries, and saw strong solidarity among them. They were encouraged by the oil crisis of the early 1970s, during which oil-exporting developing countries sought to flex their economic muscle. It was in the 1970s that the non-aligned movement of mainly Third World countries gathered some momentum and the idea of south-south co-operation was treated as a serious proposition. The developing countries were able to shape the policy agenda on a wide range of issues. For instance, the UN General Assembly declared the high seas and the ocean floor as the common heritage of mankind and imposed a moratorium on unilateral exploitation of the mineral resources of the deep seabed. Thus, the 1970s were the "golden decade" for developing countries-a time of political triumph for them.

\subsection{The New International Economic Order}

While both Eastern and Western countries were competing for influence and trying to win over new Third World country friends for their bigger political, military and strategic objectives, there was no strong opposition initially from the developed countries to ambitious proposals from developing countries. In fact, much of the socialist world sided with the aspirations of developing countries, and many capitalist countries with some socialist values (e.g. the Scandinavian countries, the Netherlands, Canada, Australia and New Zealand) had some sympathy for the developing countries' position.

Confronted with this changed situation, the leading developed countries appeared to be in a state of confusion in their approach towards the developing countries. The developed countries were still seeking to redefine their position vis-à-vis the developing countries. Many of the powerful developed countries 
had either liberal or pro-human rights governments in the 1970s, and so could not mount outright opposition to the attempts of the developing countries to create a fairer and more just international economic system.

The developing countries were not satisfied with reform of the GATT system. They were not content with a fairer trade regulating mechanism. They wanted to change the focus of the existing international economic institutions from regulating institutions to more proactive institutions, which would actively promote the ideals of international economic justice through a redistributive international economic system. Eventually, the developing countries' radical approach met with resistance from developed countries. From then on, the UN was divided into two camps: developed and developing countries. Since the developing countries had a numerical majority, they pressed ahead with resolutions within the UN, which aspired to restructure the world economy. This approach was represented by the notion of new international economic order (NIEO).

\section{The Dawn of the New Era}

While the notion of the NIEO was still on the international agenda, a powerful countermovement spearheaded the capitalist agenda in much of the Western world. This countermovement was based on privatisation, marketisation, globalisation, liberalisation of the economy and less government, both nationally and internationally. By the early 1980s China had decided to embark on economic liberalisation and openness, and during that decade other leading developing countries, such as India and Zambia, which had up to now believed in a mixed economy and had socialist tendencies, decided to abandon their traditional policy and jump on the capitalist bandwagon.

Much of the developing world found itself in a state of confusion during much of the mid-1980s, as many countries realised that their old economic and political ideologies were not improving their economies. Third World solidarity was disintegrating and developing countries now found themselves competing with each other for a trickle of foreign direct investment that was flowing from developed countries. Consequently, the late 1980s became a period of political uncertainly and economic confusion in many developing countries. As the developing world began to embrace the capitalist agenda, the communist world in Eastern Europe came under tremendous pressure to open up its doors to the outside world. A realisation on the part of the Soviet Union that it could not go on shouldering the huge economic burden of the Cold War while other countries (including its giant next-door neighbour, China) pursued economic prosperity led to the collapse of communism in Eastern Europe and the fall of the Berlin Wall.

The Soviet Union simply caved in under the pressure of capitalism. It could not sustain the arms race nor could it go on extending an expensive protective military umbrella over much of Eastern Europe. The very reasons that led to the withdrawal of the Soviet Union from its satellite states in Eastern Europe acted as catalysts for the disintegration of the Soviet empire itself. The chaos that en- 
sued resulted in disarray right at the heart of Kremlin and relegated Russia, the core of the Soviet empire, to a weak position. Ripples from the gigantic democratic revolution in Eastern Europe and the changes in the central Asian republics spread to many Asian and African states. This brought down old regimes and installed new regimes, some democratic and some semi-democratic (Giovanol, 2000).

\section{The Height of Corporate Power}

The 1990s represented the return of the "golden age" for capitalism. There was a huge swing from the 1970s heyday of the developing countries to the 1990s. During this era, capitalist countries, led by the US and the UK, came to dominate the world, both politically and economically. The 1990s offered free-marketeers and multinational companies an unprecedented opportunity to expand. The WTO agreements concluded at the end of the Uruguay Round in 1993 reflected the triumph of capitalism over socialism and ideas of a mixed economy. While Russia attempted to recover from the disorder of the early 1990s, China was quietly leaping forward on the road to economic prosperity. The disintegrated Third World was still seeking to emerge from chaos and confusion. This gave the developed countries an unprecedented opportunity to stamp their authority on more or less every area of human activity throughout the 1990s. Consequently, the 1990s became the most ambitious decade in recent times for the globalisation of Western ideologies, both political and economic (Croome, 1995).

\section{Opposition to Capitalism}

However, the triumph of capitalism and absence of any credible opposition to the activities of multinationals and free-marketeers led to excesses. The domination of the world by big business and their pursuit of profit at the expense of human rights, the environment, moral and ethical values gave rise to opposition from within. Academics, other intellectuals, environmentalists, human rights activists and other campaigners from around the world were united in their opposition to the excesses of capitalism. In the late 1990s they mounted huge and often successful protests. This time opposition came not from the developing countries, nor from the socialist camp, but from within many capitalist countries. Consequently:

1) the OECD was forced to abandon a pro-big business draft Multilateral Agreement on Investment (MAI) in 1998;

2) the WTO was forced to abandon its Seattle Conference in 1999;

3) both the World Bank and the IMF faced widespread opposition to their policies from campaigners.

As a result, a period of reckoning began towards the end of the 1990s, which led to a more balanced approach to world trade by the time the WTO met in Doha, Qatar, in November 2001. 


\section{The Definition of International Economic Law}

International economic law regulates the international economic order or economic relations among nations. However, the term "international economic law" encompasses a large number of areas. It is often defined broadly to include a vast array of topics ranging from public international law of trade to private international law of trade to certain aspects of international commercial law and the law of international finance and investment. The International Economic Law Interests Group of the American Society of International Law includes the following non-exhaustive list of topics within the term "international economic law":

1) International Trade Law, including both the international law of the World Trade Organization and GATT and domestic trade laws;

2) International Economic Integration Law, including the law of the European Union, NAFTA and Mercosur;

3) Private International Law, including international choice of law, choice of forum, enforcement of judgments and the law of international commerce;

4) International Business Regulation, including antitrust or competition law, environmental regulation and product safety regulation;

5) International Financial Law, including private transactional law, regulatory law, the law of foreign direct investment and international monetary law, including the law of the International Monetary Fund and World Bank;

6) The role of law in development;

7) International tax law; and

8) International intellectual property law.

\section{The Basis of International Economic Law}

International economic law is based on the traditional principles of international law such as:

1) Pacta sunt servanda;

2) freedom;

3) sovereign equality;

4) reciprocity;

5) economic sovereignty.

It is also based on modern and evolving principles such as:

1) the duty to co-operate;

2) permanent sovereignty over natural resources;

3) preferential treatment for developing countries in general and the least-developed countries in particular.

The sources of international economic law are the same as those sources of international law generally outlined in Article 38 of the Statute of the International Court of Justice:

"Article 38-

The Court, whose function is to decide in accordance with international law 
such disputes as are submitted to it, shall apply. 1) international conventions, whether general or particular, establishing rules expressly recognized by the contesting states; 2) international custom, as evidence of a general practice accepted as law, 3) the general principles of law recognized by civilized nations; 4) subject to the provisions of Article 59, judicial decisions and the teachings of the most highly qualified publicists of the various nations, as subsidiary means for the determination of rules of law."

\section{Economic Sovereignty}

When states began to function as politically independent and sovereign entities, they realised that one of the most important attributes of state sovereignty was economic sovereignty. Without this, political sovereignty was not complete. Asserting economic sovereignty meant having control over the economic activities of both juridical and natural persons conducting business within the country, whether nationals of that country or foreigners. Owing to a number of historical reasons, many states inherited on independence a situation in which foreign individuals or companies enjoyed certain concessions or privileges or control over the economic activities of the country concerned. In many states foreign companies or individuals controlled the natural resources and mining rights under a concession agreement entered into with the previous administration, whether colonial or otherwise.

When the country concerned wished to embark on a policy of economic development, one of the first initiatives it had to take was to consider harnessing its natural resources in accordance with its economic policies. It therefore became necessary for these states to assert sovereignty over the natural resources of the country and require that foreign individuals and companies comply with the new policy adopted by the state. In many countries it was difficult to assert economic sovereignty without doing away with the rights, concessions and privileges enjoyed by foreign individuals and companies over the country's natural resources.

However, developed countries whose nationals had gone overseas to invest and do business resisted attempts to impose national law on foreigners. They argued that existing concessions and contracts had to be honoured under international law. It was at this juncture that the concept of permanent sovereignty over natural resources was introduced in international law.

\section{Permanent Sovereignty over Natural Resources (PSNR)}

When the number of newly independent developing countries grew, these states sought to assert their complete economic sovereignty by proclaiming that they had complete and permanent sovereignty over their natural resources-regardless of any arrangements made by their previous colonial administrations. Consequently, a resolution was introduced in the UN General Assembly to this effect and was passed by an overwhelming majority of states. Paragraphs 1 and 2 of the 
famous 1962 UN General Assembly Resolution on the Permanent Sovereignty over Natural Resources (PSNR) state:

"1. The right of peoples and nations to permanent sovereignty over their natural wealth and resources must be exercised in the interest of their national development and of the well-being of the people of the state concerned;

2. The exploration, development and disposition of such resources, as well as the import of the foreign capital required for these purposes, should be in conformity with the rules and conditions which the peoples and nations freely consider to be necessary or desirable with regard to the authorisation, restriction or prohibition of such activities."

Accordingly, the resolution goes on to outline the rights of states with regard also to the expropriation and nationalisation of the assets of foreign companies:

“4. Nationalisation, expropriation or requisitioning shall be based on grounds or reasons of public utility, security or the national interest which are recognised as overriding purely individual or private interests, both domestic and foreign. In such cases the owner shall be paid appropriate compensation, in accordance with the rules in force in the state taking such measures in the exercise of its sovereignty and in accordance with international law. In any case where the question of compensation gives rise to a controversy, the national jurisdiction of the state taking such measures shall be exhausted. However, upon agreement by sovereign states and other parties concerned, settlement of the dispute should be made through arbitration or international adjudication."

The concluding paragraph of the resolution seeks to assure investor countries and foreign investors that the provisions of bilateral investment agreements will be respected:

"8. Foreign investment agreements freely entered into by or between sovereign states shall be observed in good faith; states and international organisations shall strictly and conscientiously respect the sovereignty of peoples and nations over their natural wealth and resources in accordance with the Charter and the principles set forth in the present resolution."

The provisions of the PSNR Resolution (Resolution 1803 of 1962) have been held widely as representing customary international law because of:

1) the unanimous support it received at the UN;

2) its declaratory nature of the rules of customary international law on the subject matter.

\section{Fundamental Principles of International Economic Law}

As an attempt to implement the objectives of the NIEO and to establish the norms of international economic relations, the UN General Assembly adopted as part of its resolutions on the NIEO the Charter of Economic Rights and Duties of States (CERDS) of 1974. Chapter 1 of the Charter outlines the fundamentals of international relations in the following words:

"Economic as well as political and other relations among states shall be gov- 
erned, inter alia, by the following principles:

1) Sovereignty, territorial integrity and political independence of States;

2) Sovereign equality of all States,

3) Non-aggression;

4) Non-intervention;

5) Mutual and equitable benefit,

6) Peaceful coexistence,

7) Equal rights and self-determination of peoples;

8) Peaceful settlement of disputes,

9) Remedying of injustices which have been brought about by force and which deprive a nation of the natural means necessary for its normal development,

10) Fulfilment in good faith of international obligations;

11) Respect for human rights and international obligations,

12) No attempt to seek hegemony and spheres of influence,

13) Promotion of international social justice,

14) International co-operation for development,

15) Free access to and from the sea by land-locked countries within the framework of the above principles."

These are principles of a general nature, which include both economic and political principles and reflect the trend of the early 1970s. Articles 1, 2, 4 and 5 outline the economic rights and duties of states in a more concrete manner:

"Article 1-

Every State has the sovereign and inalienable right to choose its economic system as well as its political, social and cultural systems in accordance with the will of its people, without outside interference, coercion or threat in any form whatsoever.

Article 2-

1) Every State has and shall freely exercise full permanent sovereignty, including possession, use and disposal, over all its wealth, natural resources and economic activities.

2) Each state has the right.

a) To regulate and exercise authority over foreign investment within its national jurisdiction in accordance with its laws and regulations and in conformity with its national objectives and priorities. No State shall be compelled to grant preferential treatment to foreign investment,

b) To regulate and supervise the activities of transnational corporations within its national jurisdiction and take measures to ensure that such activities comply with its laws, rules and regulations and conform with its economic and social policies. Transnational corporations shall not intervene in the internal affairs of a host State. Every State should, with full regard for its sovereign rights, cooperate with other States in the exercise of the right set forth in this subparagraph;

c) To nationalize, expropriate or transfer ownership of foreign property, in which case appropriate compensation should be paid by the State adopting such 
measures, taking into account its relevant laws and regulations and all circumstances that the State considers pertinent. In any case where the question of compensation gives rise to a controversy, it shall be settled under the domestic law of the nationalizing State and by its tribunals, unless it is freely and mutually agreed by all States concerned that other peaceful means be sought on the basis of the sovereign equality of States and in accordance with the principle of free choice of means.

Article 4-

Every State has the right to engage in international trade and other forms of economic cooperation irrespective of any differences in political, economic and social systems. No State shall be subjected to discrimination of any kind based solely on such differences. In the pursuit of international trade and other forms of economic cooperation, every State is free to choose the forms of organisation of its foreign economic relations and to enter into bilateral and multilateral arrangements consistent with its international obligations and with the needs of international economic cooperation.

\section{Article 5-}

All States have the right to associate in organizations of primary commodity producers in order to develop their national economies, to achieve stable financing for their development and, in pursuance of their aims, to assist in the promotion of sustained growth of the world economy. In particular accelerating the development of developing countries. Correspondingly, all States have the duty to respect that right by refraining from applying economic and political measures that would limit it."

Although the charter was not a "hard law" instrument having binding legal effect, many of the principles embodied in it have been regarded as representing the basis for the development of international economic law. Indeed, the charter reiterates some of the principles that were already widely accepted as representing customary rules of international law, such as the permanent sovereignty of states over their natural resources.

\subsection{The Right to Economic Development}

One of the central elements of the NIEO and CERDS was the economic development of states. This element was reinforced and strengthened through a 1986 resolution of the UN General Assembly on the right to economic development of states. The main operative provisions of this declaration read as follows:

"Article 1-

1) The right to development is an inalienable human right by virtue of which every human person and all peoples are entitled to participate in, contribute to, and enjoy economic, social, cultural and political development, in which all human rights and fundamental freedoms can be fully realised.

2) The human right to development also implies the full realisation of the right of peoples to self-determination, which includes, subject to the relevant 
provisions of both International Covenants on Human Rights, the exercise of their inalienable right to full sovereignty over all their natural wealth and resources.

Article 2-

1) The human person is the central subject of development and should be the active participant and beneficiary of the right to development.

2) All human beings have a responsibility for development, individually and collectively, taking into account the need for full respect for their human rights and fundamental freedoms as well as their duties to the community, which alone can ensure the free and complete fulfilment of the human being, and they should therefore promote and protect an appropriate political, social and economic order for development.

3) States have the right and the duty to formulate appropriate national development policies that aim at the constant improvement of the well-being of the entire population and of all individuals, on the basis of their active, free and meaningful participation in development and in the fair distribution of the benefits resulting therefrom."

Although the right to development is a difficult right to define in concrete terms and does not have much legal significance, the articulation of this right in 1986 has enabled the international community to rely on it to support and develop:

1) other principles of international trade and development;

2) special and preferential treatment for developing countries;

3) the need to address the problem of the international debt.

It can also be argued that the right to development was a contributor to the adoption of the Millennium Development Goals by the international community in 2000 , at the dawn of the new millennium.

\subsection{The Law on Natural Resources}

\subsubsection{The Stockholm Declaration 1972}

The Stockholm Declaration of the United Nations Conference on the Human Environment of $1972^{10}$ was perhaps the first major international environmental law instrument that introduced the idea of conserving natural resources onto the agenda of international economic law. Principles 2, 3 and 5 of the Stockholm Declaration speak of the need to conserve natural resources:

"Principle 2-

The natural resources of the earth including, the air, water, land, flora and fauna and especially representative samples of natural ecosystems must be safeguarded for the benefit of present and future generations through careful planning or management, as appropriate.

Principle 3-

The capacity of the earth to produce vital renewable resources must be main-

${ }^{10} 11$ ILM 1416 (1972), adopted on 16 June 1972. 
tained and, wherever practicable restored or improved.

\section{Principle 5-}

The non-renewable resources of the earth must be employed in such a way as to guard against the danger of their future exhaustion and to ensure that benefits from such employment are shared by all mankind."

The Stockholm Declaration sought for the first time to limit the right of states to exploit their natural resources (especially those which are non-renewable). As stated earlier, until this point international economic law had sought to define and strengthen the rights of sovereign states to exploit their natural resources (whether renewable or non-renewable) through various instruments, such as the concept of permanent sovereignty over natural resources. However, while endorsing this right of states, Principle 21 of the Stockholm Declaration sought to reconcile it with the need for environmental protection:

"States have, in accordance with the Charter of the United Nations and the principles of international law, the sovereign right to exploit their own resources pursuant to their own environmental policies, and the responsibility to ensure that activities within their jurisdiction or control do not cause damage to the environment of other States or of areas beyond the limits of national jurisdiction."

\subsubsection{The Charter of Economic Rights and Duties of States 1974}

Article 30 of the Charter of Economic Rights and Duties of States of 1974 included the following provision furthering the spirit of the Stockholm Declaration:

"The protection, preservation and enhancement of the environment for the present and future generations is the responsibility of all States. All States shall endeavour to establish their own environmental and developmental policies in conformity with such responsibility. The environmental policies of all States should enhance and not adversely affect the present and future development potential of developing countries. All States have the responsibility to ensure that activities within their jurisdiction or control do not cause damage to the environment of other States or of areas beyond the limits of national jurisdiction. All States should cooperate in evolving international norms and regulations in the field of the environment."

Thus, the momentum was maintained within international environmental law to limit the right to exploit natural resources in favour of the preservation of the environment. Consequently, the need to conserve natural resources and to exploit them in a sustainable manner figured prominently in the 1982 World Charter for Nature. ${ }^{11}$

\subsubsection{World Charter for Nature 1982}

The preamble to this Charter declares that "man can alter nature and exhaust natural resources by his action or its consequences and, therefore, must fully recognise the urgency of maintaining the stability and quality of nature and of

${ }^{11}$ UNGA Res. 37/7; 22 ILM 455 (1983), adopted on 28 October 1982. 
conserving natural resources". The Charter then goes on to state that:

"The degradation of natural systems owing to excessive consumption and misuse of natural resources, as well as to failure to establish an appropriate economic order among peoples and among states, leads to the breakdown of the economic, social and political framework of civilisation."

\subsubsection{UN Convention on the Law of the Sea 1982}

The need to pay attention to the preservation of the environment while exploiting natural resources was also reflected in the Law of the Sea Convention adopted in the same year. Article 193 of this Convention provides that:

"States have the sovereign right to exploit their natural resources pursuant to their environmental policies and in accordance with their duty to protect and preserve the marine environment."

Thus, from the 1980s onwards the idea developed that the right of states to freely dispose of their wealth and natural resources was subject to the concepts of:

1) the preservation of the environment;

2) conservation of natural resources;

3) the sustainable use and development of such resources.

These concepts were also gradually finding their way into the body of international economic law. The principles of international environmental law had started to influence the international economic law principles relating to the exploitation of natural resources. Other environmental treaties (whether global or regional) relating to specific regions (e.g. Africa or Southeast Asia) or the protection of specific geographical areas (e.g. wetlands) or specific natural resources (e.g. wildlife, flora and fauna) had started lending their support to the idea that the international economic law-based right of a state to exploit their natural resources was subject to certain principles of international environmental law. Examples are:

1) the 1968 African Convention on the Conservation of Nature and Natural Resources;

2) the 1985 ASEAN Agreement on the Conservation of Nature and Natural Resources;

3) the Ramsar Convention on Wetlands of 1971;

4) the 1973 Convention on International Trade in Endangered Species of Wild Fauna and Flora;

5) the 1979 Bonn Convention on the Conservation of Migratory Species of Wild Animals;

6) the 1991 Protocol on Environmental Protection to the Antarctic Treaty.

\subsubsection{The Brundtland Commission}

The 1985 report of the World Commission on Environment and Development (WCED) (popularly known as the "Brundtland Commission") popularised the phrase "sustainable development", embodying both states' right to economic 
development and their obligation to pay particular attention to any degradation of the environment resulting from development activities. In other words, it was a phrase coined to express the balance that had to be reached between the right of states to use or exploit their natural resources in accordance with their developmental policies and the duty inherent upon them to preserve the environment in carrying out such developmental activities.

The Commission defined the term "sustainable development" as "development that meets the needs of the present without compromising the ability of future generations to meet their own needs". ${ }^{12}$ In the opinion of the Commission, economic development that undermined the environment or led to the excessive exploitation of natural resources to the detriment of future generations was not sustainable development. Hence, it was felt that the need to preserve and make rational use of the natural resources of a country in the interests of the environment and future generations was inherent in the concept of sustainable development.

\subsubsection{The Rio Conference 1992}

Following the groundwork done by the Brundtland Commission on broad concepts such as sustainable development that embraced not only the environment, but also all other economic activities regulated by international economic law, the UN decided to convene a special Conference on Environment and Development in Rio in 1992. Unlike the Stockholm Conference (which was on the human environment) the Rio Conference was going to consider both the environment and development, displaying the importance attached to the elements embodied in both words. Principle 1 of the resulting Rio Declaration on Environment and Development declared that human beings were at the centre of concerns for sustainable development.

The Rio Declaration was adopted unanimously by the Rio Conference - the largest conference ever convened in the history of international relations. It seeks to recognise:

1) the right of states under international economic law to exploit their own resources pursuant to their own environmental policies';

2) the duty of states international environmental law to ensure that activities within their jurisdiction or control do not cause damage to the environment of other states or of areas beyond the limits of national jurisdiction.

Principle 2 of the Declaration reads:

"States have, in accordance with the Charter of the United Nations and the principles of international law, the sovereign right to exploit their own resources pursuant to their own environmental and developmental policies, and the responsibility to ensure that activities within their jurisdiction or control do not cause damage to the environment of other States or of areas beyond the limits of national jurisdiction."

12“Our common future: World Commission on Environment and Development”, Oxford University Press, 1987, p. 43. 
The language used here draws heavily on the provisions of:

1) Principle 21 of the Stockholm Declaration;

2) Article 30 of the 1974 Charter of Economic Rights and Duties of States;

3) the 1962 UN Declaration on Permanent Sovereignty of States over their Natural Resources (PSNR).

The tension between the right of states to exploit their natural resources and the need to conserve natural resources has been a tension between international economic law and international environmental law. The law of sustainable development has brought these two together, adding a sustainable development dimension to various principles of international economic law such as:

1) equity;

2) the right to economic development;

3) the right of permanent sovereignty of states over their natural resources.

Although the Rio Declaration widened the scope of the principle of sustainable development to include not only conservation of natural resources, but also a host of other elements, it gave this principle a credible international standing. What is more, Principle 12 of the Rio Declaration injects the sustainable development dimension into international economic law issues and highlights the importance of international economic law principles for the effective operation of the rules of international environmental law:

"Principle 12-

States should cooperate to promote a supportive and open international economic system that would lead to economic growth and sustainable development in all countries, to better address the problems of environmental degradation. Trade policy measures for environmental purposes should not constitute a means of arbitrary or unjustifiable discrimination or a disguised restriction on international trade. Unilateral actions to deal with environmental challenges outside the jurisdiction of the importing country should be avoided. Environmental measures addressing trans-boundary or global environmental problems should, as far as possible, be based on an international consensus."

\subsubsection{The UN Convention on Biological Diversity 1992}

The Rio Declaration was not the only outcome of the Rio Conference. The 1992 UN Convention on Biological Diversity was opened for signature at the Rio Conference and was signed by 157 states and the European Union. The preambular paragraphs of the Convention reaffirm the sovereign rights of states over their own biological resources. However, the Convention stresses at the same time that states are responsible for:

1) conserving their biological diversity;

2) using their biological resources in a sustainable manner.

Article 6 of the Convention states-

"Each Contracting Party shall, in accordance with its particular conditions and capabilities.

a) Develop national strategies, plans or programmes for the conservation and 
sustainable use of biological diversity or adapt for this purpose existing strategies, plans or programmes which shall reflect, inter alia, the measures set out in this Convention relevant to the Contracting Party concerned; and

b) Integrate, as far as possible and as appropriate, the conservation and sustainable use of biological diversity into relevant sectoral or cross-sectoral plans, programmes and policies."

Thus, although there are still not any specific international treaties regulating the exploitation of certain natural resources (e.g. oil, gas, minerals and land), the discussion in the preceding paragraphs demonstrates that these natural resources must be exploited:

1) in a sustainable manner;

2) with due respect for the environment.

\section{Conclusions}

Traditionally speaking, international economic law did not pay much attention to environmental concerns. International economic and commercial activities continued to expand until recently with little concern for the harm done to the environment by these activities. The main international economic agenda in the post-Second World War period involved promoting the free movement of goods and capital across borders and enabling states to exploit their natural resources to the maximum extent possible for their economic development. International economic law tried to catch up with this expansion of international economic and commercial activities and regulate wherever and whichever aspect possible, but without paying much serious attention to environmental aspects of economic development.

However, more recently, developments taking place within international environmental law have influenced the development of international economic law. The international environmental law principle of sustainable development, a relatively new principle, has had a profound impact on international economic law. ${ }^{13}$ Within the UN's economic development agenda, a significant shift in emphasis in the theory of economic development began in 1987 with the introduction of the concept of sustainable development, which sought to impose some restraints on economic development in favour of the need to protect the environment. This new idea also sought to unite both the developing and developed countries in pursuit of a common agenda. Implicit in the idea of sustainable development was that the developing countries would receive financial assistance from the developed countries to carry out developmental projects which:

1) do not harm the environment;

2) take into account concepts such as intergenerational equity.

The development agenda of the world was no longer supposed to be a struggle between the developed and developing countries. Rather, both groups of states

${ }^{13}$ For a recent leading work in this area, see Weiss, F., "International economic law with a human face", Kluwer Law International, 1998. 
were supposed to work jointly to achieve sustainable economic development. All states had a duty to contribute to the process, but the level of contribution would be guided by the concept of common but differentiated responsibility. This idea was endorsed by the Rio Declaration of 1992 and other instruments adopted by the Rio Conference.

This is the historical background to the development in modern times of international economic law. As we can see, the history of international economic law is basically the history of the interplay between law and international politics. At its heart have been the national interests of the major powers of the day and their desire to fashion international economic law to suit their priorities.

\section{Conflicts of Interest}

The authors declare no conflicts of interest regarding the publication of this paper.

\section{References}

Cassese, A. (2005). International Law. Oxford: Oxford University Press.

Croome, J. (1995). Reshaping the World Economy: A History of the Uruguay Round. Geneva: World Trade Organization.

Fox, H. (1992). International Economic Law and Developing States: An Introduction (Vol. II). London: British Institute of International and Comparative Law.

Giovanoli, M. (2000). International Monetary Law: Issues for the New Millennium. Oxford: Oxford University Press.

Lowenfeld, A. F. (2003). International Economic Law. Oxford: Oxford University Press.

Muchlinski, P. (1999). Multinational Enterprises and the Law. Oxford: Blackwell.

Qureshi, A. (1999). International Economic Law. London: Sweet \& Maxwell,.

Qureshi, A. (ed.) (2002). Perspectives in International Economic Law. Kluwer Law International: Alphen aan den Rijn.

Schrijver, N. (1997). Sovereignty over Natural Resources: Balancing Rights and Duties. Cambridge: Cambridge University Press. https://doi.org/10.1017/CBO9780511560118

Seidl-Hohenveldern, I. (1992). International Economic Law. Leiden: Martinus Nijhoff.

WTO Secretariat (1999). The Legal Texts: The Results of the Uruguay Round of Multilateral Trade Negotiations. Cambridge: Cambridge University Press. 